\title{
Impact of Front Line Demonstration on the Yield and Economics of Coriander in Kota District of Rajasthan, India
}

\author{
M.K. Poonia ${ }^{1}$, Mahendra Singh ${ }^{1}$, B.L. Dhaka ${ }^{2}$, R.K. Bairwa ${ }^{2}$ and Bheru Lal Kumhar ${ }^{1}$ \\ ${ }^{1}$ Department of Horticulture, Krishi Vigyan Kendra, Borkhera, Kota Agriculture University, \\ Kota (Rajasthan), India-324001 \\ ${ }^{2}$ Department of Agronomy, Krishi Vigyan Kendra, Bundi, Agriculture University, Kota \\ (Rajasthan), India-324001 \\ *Corresponding author
}

A B S T R A C T

Keywords

Coriander, Farmers practices, Frontline demonstration and yield.

Article Info

Accepted:

24 February 2017

Available Online:

10 March 2017
The study was carried out in NICRA village Chomakot of Kota district during 2012-13 to 2015-16. Total 80 front line demonstrations were conducted on coriander in 40 ha by the active participation of the farmers with the objective of improved technologies of coriander production potentials. The improved technologies consist improved variety (R.Cr.436), balanced fertilizers (soil test based) application and integrated disease and pest management, etc. The demonstrated recorded an average yield ranging from $1210 \mathrm{~kg}$ to $1770 \mathrm{~kg} / \mathrm{ha}$ with a mean of $1542 \mathrm{~kg} / \mathrm{ha}$. The per cent increase yield in demonstration ranged from $5.22 \%$ to $13.50 \%$ in the respective years. The average extension gap, technology gap and technology index were $136.55 \mathrm{~kg} / \mathrm{ha}, 457.50 \mathrm{~kg} / \mathrm{ha}$ and $22.87 \%$, respectively. The demonstrated field gave higher net return Rs. 35700/- to Rs. 59900/ ha and $\mathrm{B}: \mathrm{C}$ ratio 1.64 to 2.83 with mean Rs. $54550 /$ ha and 2.33 , respectively. Present results clearly show that the yield and economics of Coriander can be boost up by adoption of recommended technology.

\section{Introduction}

India is known as the "Land of Spices." It is the largest producer, consumer as well as exporter of spices and spice products in the world. Out of the total 63 spices grown in India, seed spices contribute about $36 \%$ share in area with $70 \%$ in production of total spices. Rajasthan is a leading producer of seed spices particulars coriander, cumin, fenugreek, fennel, ajwain etc. Coriander (Coriandrum sativum L.) is grown mainly in south and south eastern plains of Rajasthan comprising Kota, Bundi, Baran and Jhalawar districts, and accounts for entire production in
Rajasthan. The multiple uses of coriander, the productivity in Kota district in particular is very low, primarily due to unavailability of suitable variety(s) as well as lack of improved production technologies, more specifically the method of sowing and nutrient management. The productivity of coriander could be increased by adopting recommended scientific and sustainable management production practices (Dhaka et al., 2015 and Verma et al., 2016). Front line demonstration is the new concept of field demonstration with main objective to demonstrated newly 
released variety with improved practices technologies and its management practices at farmer's field under different agro climatic regions of the country with varying farming situations. Productivity of coriander per unit area can be increased by adopting feasible, scientific and sustainable management practices by selecting a suitable variety. With this in view, front line demonstrations held at farmer's field, in a systemic manner, to show case the high yielding new varieties, to convince them to about the potential of improved production technologies to enhance yield of coriander.

\section{Materials and Methods}

The frontline demonstrations were conducted by several institutes or organizations in Rajasthan but due to paucity of time and proximity, study was confined to FLDs conducted by KVK Borkhera, Kota district of Rajasthan. During 2012-13 to 2015-16, a total 80 front line demonstrations on coriander variety R. Cr. 436 was conducted at farmer's field in the NICRA village Chomakot. The yield and economic performance of frontline demonstrations, the data on output were collected from FLDs as well as local plots and finally the grain yield, cost of cultivation, net returns with the benefit cost ratio was worked out. For the purpose of investigation, Chomakot villages of Kota district, where FLDs were conducted during 2012-13 to 2015-16. For selection of beneficiary farmers, a list of farmers where FLDs on coriander were conducted during Rabi 2012-13 to 201516 was prepared and taking equal representation. The data were collected through personal contacts with the help of well structured interview schedule. The gathered data were processed, tabulated, classified and analyzed in terms of mean percent score and ranks in the light of objectives of the study. More than 10 percent difference between beneficiary and non beneficiary farmers' was considered as significant difference. The extension gap, technology gap and technology index were calculated using the formula as suggested by Samui et al., (2000).

Extension gap $\left(\mathrm{qha}^{-1}\right)=$ Demonstration yield Farmer's yield

Technology gap $\left(\mathrm{qha}^{-1}\right)=$ Potential yieldDemonstration yield

Technology index $(\%)=[$ Potential yield Demonstration yield / Potential yield] x 100

\section{Results and Discussion}

A comparison of the productivity level between front line demonstrations and local checks is shown in Table 1. It is evident from results that under the demonstrate plot, performance of coriander (yield) was sustainable higher than that in the local check in all the years of the study (2012-13 to 201516). Yield in coriander under demonstration ranged from (1210-1770 kg/ha) during the period under study. Technological intervention, thus, enhanced yield to a tune of $10.18 \%, 13.50 \%, 5.22 \%$ and $12.00 \%$, respectively, over the local check. Fluctuations in yield observed over the years were mainly on account of variation in soil moisture availability, rainfall, sowing time and pest and disease attack. Similar enhancement in yield in coriander under front line demonstrations was documented by Dhaka et al., 2015; Lal et al., 2016; Meena et al., 2016 and Verma et al., 2016.

Yield in front line demonstration and potential yield of the crop was compared for estimating yield gaps. These gaps were further categorised as technology and extension gaps. Technology gap indicates a gap in demonstration yield over the potential yield, and this was 430, 380, 790 and 230 $\mathrm{kg} / \mathrm{ha}$ during 2012-13, 2013-14, 2014-15 and 2015-16, respectively (Table 2). The 
technology gap observed may be attributed to dissimilarities in soil fertility, salinity and to erratic rainfall and other vagaries of weather in the demonstration areas. Hence, to narrow down the gap between the two types of yield in different varieties, location specific recommendation may become necessary.
Extension gap ranged from 70 to $190 \mathrm{~kg} / \mathrm{ha}$ during the period under study (Table 2). A wide extension gap emphasizes the need to educate farmers using various means to facilitate adoption of improved production technologies, to reverse this trend.

Table.1 Yield and yield difference of coriander under front line demonstrations

\begin{tabular}{|c|c|c|c|c|c|}
\hline \multirow[t]{2}{*}{ Year } & \multirow{2}{*}{$\begin{array}{l}\text { No. of } \\
\text { FLDs }\end{array}$} & \multicolumn{2}{|c|}{ Yield (kg/ha) } & \multirow{2}{*}{$\begin{array}{l}\text { Additional yield over } \\
\text { local check (kg/ha) }\end{array}$} & \multirow{2}{*}{$\begin{array}{c}\text { Per cent increase yield } \\
\text { over Local Check }\end{array}$} \\
\hline & & FLD & Local Check & & \\
\hline 2012-13 & 20 & 1570 & 1425 & 145 & 10.18 \\
\hline 2013-14 & 20 & 1620 & 1480 & 140 & 13.50 \\
\hline 2014-15 & 20 & 1210 & 1150 & 70 & 5.22 \\
\hline 2015-16 & 20 & 1770 & 1580 & 190 & 12.00 \\
\hline Mean & & 1542 & 1408 & 136.25 & 10.22 \\
\hline
\end{tabular}

Table.2 Yield gap and technology index in front line demonstrations

\begin{tabular}{|c|c|c|c|c|}
\hline Year & No. of FLD & $\begin{array}{c}\text { Technology gap } \\
(\mathbf{K g} / \mathbf{h a})\end{array}$ & $\begin{array}{c}\text { Extension Gap } \\
(\mathbf{K g} / \mathbf{h a})\end{array}$ & $\begin{array}{c}\text { Technology } \\
\text { Index (\%) }\end{array}$ \\
\hline $2012-13$ & 20 & 430 & 145 & 21.5 \\
\hline $2013-14$ & 20 & 380 & 140 & 19.0 \\
\hline $2014-15$ & 20 & 790 & 70 & 39.5 \\
\hline $2015-16$ & 20 & 230 & 190 & 11.5 \\
\hline Mean & & $\mathbf{4 5 7 . 5}$ & $\mathbf{1 3 6 . 2 5}$ & $\mathbf{2 2 . 8 7}$ \\
\hline
\end{tabular}

Table.3 Economics of front line demonstrations

\begin{tabular}{|c|c|c|c|c|c|c|c|c|}
\hline \multirow{2}{*}{ Year } & $\begin{array}{c}\text { Cost of Cultivation } \\
\text { (Rs/ha) }\end{array}$ & \multicolumn{2}{c|}{$\begin{array}{c}\text { Gross return } \\
\text { (Rs/ha) }\end{array}$} & \multicolumn{2}{c|}{$\begin{array}{c}\text { Net return } \\
\text { (Rs/ha) }\end{array}$} & \multicolumn{2}{|c|}{ B:C ratio } \\
\cline { 2 - 9 } & FLD & $\begin{array}{c}\text { Local } \\
\text { Check }\end{array}$ & FLD & $\begin{array}{c}\text { Local } \\
\text { Check }\end{array}$ & FLD & $\begin{array}{c}\text { Local } \\
\text { Check }\end{array}$ & FLD & $\begin{array}{c}\text { Local } \\
\text { Check }\end{array}$ \\
\hline $2012-13$ & 20500 & 19200 & 67950 & 58500 & 47450 & 39300 & 2.31 & 2.04 \\
\hline $2013-14$ & 21100 & 19900 & 81000 & 74000 & 59900 & 54100 & 2.83 & 2.71 \\
\hline $2014-15$ & 21800 & 20400 & 57500 & 52900 & 35700 & 32500 & 1.64 & 1.60 \\
\hline $2015-16$ & 22500 & 21000 & 79650 & 71000 & 57150 & 50000 & 2.54 & 2.38 \\
\hline Mean & $\mathbf{2 1 4 7 5}$ & $\mathbf{2 0 1 2 5}$ & $\mathbf{7 1 5 2 5}$ & $\mathbf{6 4 1 0 0}$ & $\mathbf{5 4 5 5 0}$ & $\mathbf{4 3 9 7 5}$ & $\mathbf{2 . 3 3}$ & $\mathbf{2 . 1 8}$ \\
\hline
\end{tabular}


Fig.1 Coriander

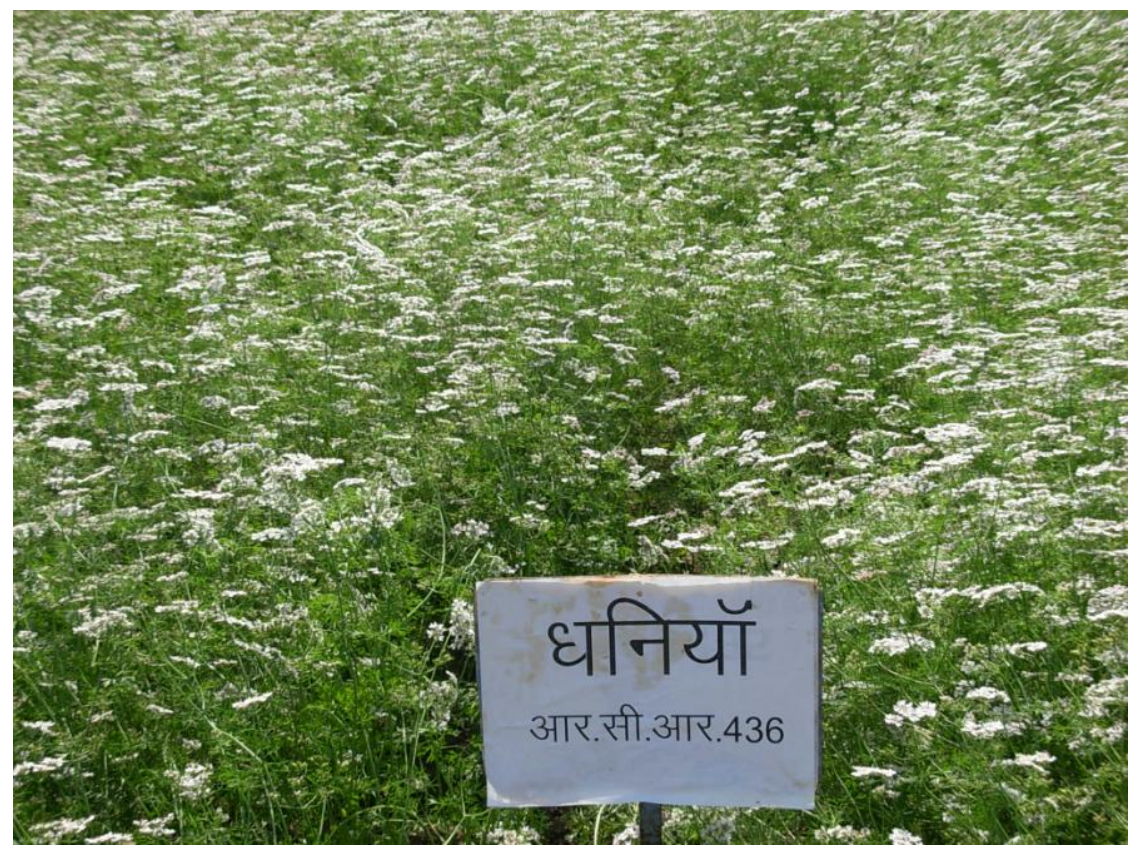

Greater use of the latest, improved production technologies applied to high yielding varieties can subsequently bridge this extension gap between demonstration yield and farmer's yield. New technologies, may, eventually lead farmers into discontinuing obsolete varieties. Technology index refer to the feasibility of variety at farmers field. A lower the value of technology index (mean 22.87\%) more is the feasibility (Table 2). This finding corroborates results of Dhaka et al., 2010; Dhaka et al., 2015; Lal et al., 2016; Meena et al.2016 and Verma et al., 2016.

The economics of growing coriander under front line demonstrations were estimated and results are presented in Table 3. Economic analysis of yield performance revealed that besides higher production, participating farmers in FLDs realized a higher price of than produce compared to that in the local checks during the period under study. This was so because of a better quality of the produce. front line demonstrations recorded higher mean gross return (Rs. 71525/ha) and mean net returns (Rs. 54550/ha) with average benefit: cost ratio (2.33) compared to the local checks in our study. These results are in line with finding of Dhaka et al., 2015; Lal et al., 2016; Meena et al., 2016 and Verma et al., 2016. On the basis of above finding in present study, it is concluded that front line demonstrations of improved technology reduces technology gap to a considerable extent, thus leading to increased productivity of coriander in Kota district of Rajasthan. This also improved linkages between farmers and scientists, and built confidence for adoption of the improved technology. Productivity enhancement under FLDs over farmer practices of coriander cultivation created a greater awareness, and motivated other farmers not growing coriander to adopt improved technologies in this seed spice crop i.e. coriander.

\section{References}

Dhaka, B.L., Meena, B.S. and Suwalka, R.L., 2010. Popularization of improved maize production technology through frontline demonstrations in south-eastern Rajasthan. J. Agri. Sci., 1(1): 3942. 
Dhaka, B.L., Poonia, M.K., Meena, B.S. and Bairwa, R.K. 2015. Yield and economic viability of coriander under front line demonstrations in Bundi district of Rajasthan. J. Hortl. Sci.., 10(2): 226-28

Lal, G., Mehta, R.S., Meena, R.S., Meena, N.K. and Choudhry, M.L. 2016. Impact of front line demonstration (FLDS) on yield enhancement of coriander: A case study in TSP area of Pratapgarh. E News Letter ICAR- National Research Centre on Seed Spices, 8(3): 5-6

Meena, K.C., Singh, D.K., Gupta, I.N., Singh, B., Meena, S.S. 2016. Popularazation of coriander production technologies through front line demonstrations in Hadauti region of Rajasthan. Int. J. Seed Spices, 6(2): 24-29

Samui, S.K., Maitra, S., Roy, D.K., Mondal, A.K. and Saha, D. 2000. Evaluation of front line demonstration on groundnut (Arachis hypogea L.) in Sundarbans. J. of Indian Society of Coastal Agri. Re., 18(2): 180-183.

Verma, Arjun Kumar, Singh, Mahendra, Singh, Navab, Jeenger, K.L. and Verma, J.R. 2016. Dissemination of improved practices of coriander through FLDS in Zone V of Rajasthan province. Int. J. Sci. Envion. Tech., 5(5): 3320-27.

\section{How to cite this article:}

Poonia, M.K., Mahendra Singh, B.L. Dhaka, R.K. Bairwa and Bheru Lal Kumhar. 2017. Impact of Front Line Demonstration on the Yield and Economics of Coriander in Kota District of Rajasthan, India. Int.J.Curr.Microbiol.App.Sci. 6(3): 2344-2348. doi: http://doi.org/10.20546/ijcmas.2017.603.268 